vast demands on psychiatry. Thus only a few offenders might get adequate rehabilitative therapy. A wiser approach would be to regard sex crimes as part of the general problem of criminal deviation, and to concentrate the limited therapeutic facilities available on those criminals, whether or not sexually abnormal, who would benefit most from treatment. New York's statute, because it applies only to convicted persons rather than to sexual psychopaths as a class, may be one step in this direction. Unimplemented, this law will prove as bad as other sex offender statutes. ${ }^{50}$ If administered successfully, however, it might well pioneer a significant advance in the penal treatment of all mentally abnormal criminals.

\title{
ICC EXTENSION OF THE SHREVEPORT DOCTRINE*
}

IN the course of its efforts to regulate the railroads, the Interstate Commerce Commission has attempted to extend its authority to include jurisdiction over intrastate rates. It partly succeeded in $1914,{ }^{1}$ when the ruling in the Shreveport Rate Case ${ }^{2}$ sanctioned its authority to raise these rates in accordance with complaints by interstate shippers that the difference between inter- and intrastate rates resulted in undue preference to intrastate shippers. Six years later, its authority to regulate intrastate commerce in the interest of interstate commerce was enacted into Section 13 of the Interstate Commerce Act. ${ }^{3}$ In addition, the Commission was authorized to hear complaints initiated by interstate railroads as well as shippers. ${ }^{4}$

50. For a strong condemnation of sexual psychopath laws see Deutsch, Sober Facts About Sex Crime, Colliers, Nov. 25, 1950, p. 15.

* Docket No. 30455, decided July 31, 1950.

1. For a history of attempts prior to 1914, see Coleman, The Evolution of Federal' Regulation of Intrastate Rates: The Shreveport Rate Cases, 28 HARv. L. REv. 34 (1914).

2. Houston \& Texas Ry, v. United States, 234 U.S. 342 (1914).

3. Interstate Commerce Act $\S \S 13(3), 13(4), 49$ U.S.C. $\S \S 13(3), 13(4)$ (1946), added by Transportation Act of Feb. 28, 1920, 41 STAr. 484 (1920).

$\S 13(4)$ reads as follows:

"Whenever in any such investigation the commission, after full hearing, finds that any such rate, fare, charge, classification, regulation, or practice causes any undue or unreasonable advantage, preference, or prejudice as between persons or localities in intrastate commerce on the one hand and interstate or foreign commerce on the other hand, or any undue, unreasonable, or unjust discrimination against interstate or foreign commerce, which is hereby forbidden and declared to be unlawful, it shall prescribe the rate, fare, or charge, or the maximum or minimum, or maximum and minimum, thereafter to be charged, and the classification, regulation, or practice thereafter to be observed, in such manner as, in its. judgment, will remove such advantage, preference, prejudice, or discrimination. Such rates, fares, charges, classifications, regulations, and practices, shall be observed while in effect by the carriers parties to such proceeding affected thereby, the law of any State or the decision or order of any State authority to the contrary notwithstanding."

4. $\S 13(3)$, see note 3 supra, gave the railroads as well as shippers and others affected 
Most Section 13 proceedings are in fact brought by railroads. ${ }^{5}$ They typically arise as follows: after the ICC has granted interstate increases in a large section of the country, the railroads in the area affected petition the states for comparable intrastate increases. After hearings and decisions by the state commissions, the railroads, if dissatisfied, complain to the ICC. ${ }^{6}$

A recent ICC decision, Alabama Intrastate Rates and Charges 1950,7 represents an important departure from this procedure. The railroads filed rate schedules with the Alabama commission requesting general intrastate increases. Their petition was rejected on procedural grounds, with instructions to refile and request a hearing on the merits. Without waiting for further state action, the railroads applied for Section 13 relief. ${ }^{8}$ The ICC, over protests from Alabama and from intrastate shippers, ${ }^{9}$ issued an

the right to attack state-imposed rates. $\$ 13(3)$ is as follows: "Whenever in any investigation under the provisions of this chapter, or in any investigation instituted upon petition of the carrier concerned, which petition is authorized to be filed, there shall be brought in issue any rate, fare, charge, classification, regulation, or practice, made or imposed by authority of any State, the commission, before proceeding to hear and dispose of such issue, shall cause the State or States interested to be notified of the proceeding. The commission may confer with the authorities of any State having regulatory jurisdiction over the class of persons and corporations subject to this chapter or chapter 12 of this title with respect to the relationship between rate structures and practices or carriers subject to the jurisdiction of such State bodies and of the commission; and to that end is authorized and empowered, under rules to be prescribed by it, and which may be modified from time to time, to hold joint hearings with any such State regulating bodies on any matters wherein the commission is empowered to act and where the rate-making authority of a State is or may be affected by the action taken by the commission. The commission is also authorized to avail itself of the cooperation, services, records, and facilities of such State authorities in the enforcement of any provision of this chapter or chapter 12 of this title." [Emphasis added.]

Prior to the 1920 statute, railroads had no standing to challenge intrastate rates before the ICC. The railroads in the Shreveport Case defended existing intrastate rates. Houston \& Texas Ry. v. United States, 234 U.S. 342 (1914). The ICC in that case was given the power to regulate intrastate rates under $\$ 3(1)$ of the Act, 49 U.S.C. $\$ 3(1)$ (1929), 24 STAT. 380 (1887), amended, 41 STAT. 479 (1920); 234 U.S. 342, 355 et. seq. (1914). § 3(1) provides that "[i]t shall be unlawful for any common carrier . . . to make, give, or cause any undue or unreasonable preference or advantage to any particular person, company, firm, corporation, . . . locality. . . ." This section was clearly directed against the carriers themselves, rather than against any state authority. 234 U.S. 342, 356.

5. Of 150 cases involving intrastate rate changes between September 1927 and January 1938, listed in Lust, Consolidated Digest of Decisions under the InTERState COMAMERCE ACT, vols. 5-9 (1931, 1933, 1936, 1938, 1941), including applications for modifcations of previous decisions, railroads initiated 106.

6. E.g., Texas Intrastate Rates, 273 I.C.C. 749 (1949); Increases in Kansas Freight Rates and Charges, 231 I.C.C. 137 (1938); Arkansas Rates and Fares, 59 I.C.C. 471 (1920).

7. Docket No. 30455, decided July 31, 1950.

8. Id. at 17 (dissenting opinion).

9. Id. at 12-14.

The Alabama commission had rejected the proposed rate increases on the ground that they were filed improperly, and argued before the ICC that there had been no attempt by the railroads to secure a decision by the state, and that therefore the state had been deprived of an opportunity to decide the case. In its brief, the state commission also argued on the merits. 
-order requiring that intrastate rates be raised at least to the equivalent interstate level. ${ }^{10}$

In asserting its power to issue this order before a prior decision by the state, the ICC relied upon Florida v. United States. ${ }^{11}$ There, the Commission had ordered log rates within Florida to be raised to the interstate level in order to prevent undue prejudice to Georgia shippers. On appeal to the Supreme Court, Florida argued, among other things, that it had not yet had an opportunity to rule upon the lawfulness of the intrastate rates. Although ruling in favor of Florida, the Court rejected this contention, stating that such action by the state was unnecessary. ${ }^{12}$

The Florida case is an incomplete analogy. There it was interstate shippers from Georgia who were attacking the Florida rates. In that situation, the sole ground on which any attack can be made is prejudice to interstate commerce, a question not within the jurisdiction of a state commission. When, however, as in the Alabama case, the complainant is a railroad

Intrastate shippers opposing the changes included cotton dealers, a nylon garments fabricator, and representatives of a number of commercial firms at Montgomery. Id. at 13. The total intrastate tonnage affected by the decision was estimated to be 164,981 tons, which constituted $39 \%$ of Alabama's total shipping interstate and intrastate. Nearly a quarter of this consisted of intrastate shipping of mine products. Id. at 6 .

10. With the exception of commodities withdrawn from consideration by the railroad. Id. at 15-16. These commodities were: sulphuric acid, brick, canned goods, asphaltic limestone, petroleum and its products, cast iron pipe, road aggregates, road building material, Ioofing, and expanded slag. No reason for the railroad's action with respect to these commodities is given in the opinion, but it is possible that competition with motor and water carriers influenced their decision.

11. 282 U.S. 194 (1931).

The ICC also cited three of its own cases, which are listed in note 6 supra. The Texas case is closest to the Alabama decision. There the state commission had held hearings, but had not had the opportunity to rule on certain of the commodities involved in the Section 13 application. The ICC, stating that the interests of Texas would not be injured by its inability to rule on them, cited Florida $v$. United States and ordered all of the rates to be raised.

In neither of the other two cases cited by the ICC was the state commission in fact deprived of an opportunity for a hearing and decision. In the Kansas case, the protest was that the railroads had not exhausted their state remedies since they had not applied for a rehearing. In contrast to the Alabama case, the Kansas commission had already held an initial hearing on the requested rate increases and had rendered a decision. In the Arkansas case, the state protested that state remedies had not been exhausted beçause the railroads had not applied to the state courts to suspend a controlling statute. The ICC, stating that the state commission had already ruled on the case to the extent of its powers, overruled the objection.

12. "To hold, as some of the appellants urge, that there can be no adjustment of intrastate rates by the Interstate Commerce Commission so far as may be needed to protect interstate commerce until the State itself has first 'sat in judgment on the issue of the lawfulness of those intrastate rates' would be to impose a limitation not required by the terms of the statute and repugnant to the grant of authority." 282 U.S. 194, 210. The sentence here quoted concludes the Court's refutation of appellants' argument that because the state had not "made or imposed" the rates in question, but had simply permitted them to go into effect, the ICC had no power to change the rates. 
operating within the state, an original attack on the intrastate rates can be made in the state commission on the ground that the rates are unreasonably low, so that the railroad is unable to make a fair return. ${ }^{13}$

Section 13 itself makes no mention of prior state hearings. It authorizes cooperation with the states in matters which affect their interests, ${ }^{14}$ and prescribes the criteria which the ICC is to apply in deciding intrastate rate cases. ${ }^{15}$ The words and legislative history of the statute indicate that Congress intended to implement the federal power to prevent injury to interstate commerce, and at the same time, to preserve the state power over intrastate rates to the extent possible. ${ }^{16}$ Therefore, a determination of the legality under the statute of the ICC's procedure in the Alabama case should depend upon a balancing of necessity to interstate commerce against the resulting loss to the states. ${ }^{17}$

The Alabama decision will prevent consideration of all of the possible consequences of changing intrastate rates. The ICC is limited in its deliberations solely to the question of harmful effects on interstate commerce. ${ }^{18}$ Specifically, it may examine the rates only to determine if they

13. State statutes typically require that intrastate rates be "just and reasonable." This phrase includes, either by statutory or judicial amplification, the idea that the railroads are entitled to a fair return. See, e.g., AlA. CoDE, tit. 48, § 52 (1940); N.Y. PuB. Serv. Law, Art. 3, § 49 (1938); 1 Page's OHIo Gen. Code ANN. § 504 (1946); Railroad v. Pub. Util. Com., 160 O.S. 120, 155 N.E. 862 (1927).

When the railroads petition the ICC for rate increases on the grounds of unjust discrimination against interstate commerce, they are, in effect, asserting that they are not making a fair return on the intrastate portion of their traffic. See note 20 infra.

14. Interstate Commerce Act $\S 13(3)$. See note 4 supra.

15. Interstate Commerce Act $\$ 13(4)$. See note 3 supra.

16. See H.R. ReP. No. 456, 66th Cong., 1st Sess. 20 (1919); H.R. ReP. No. 650, 66th Cong., 2d Sess. 64-65(1920); MacVeage, The Transportation Act, 1920, 314 et seq. (1923).

17. The Supreme Court has long been attempting to balance state and federal powers over railroad rates. In the Minnesota Rate Cases, 230 U.S. 352 (1913), the Court upheld the power of a state to set intrastate rates against the attack of the railroads that the relationship between these and interstate rates resulted in inevitable discrimination against interstate commerce. In the Shreveport Rate Case, 234 U.S. 342 (1914), it upheld the power of the ICC to protect against preference and prejudice in favor of intrastate shippers. North Carolina v. United States, 325 U.S. 507 (1945), contains a recent discussion of this problem. There, the Court states that the primary power rests with the states; the right of the ICC to interfere depends upon clear and certain findings that the prohibited degree of prejudice or discrimination has been reached, a point "not always easy to mark." Id. at 511.

It follows that the damage to interstate commerce must be substantial and clearly shown before the Commission has the power to act. In the situation presented in the Alabama case, a showing that the action taken was necessary to prevent serious harm to interstate commerce would justify such action. On the other hand, a showing that the state has been harmed by the procedure followed, and that interstate commerce could have been protected by a different procedure, would serve to reverse the decision.

18. From the Shreveport Rate Case, 234 U.S. 342, (1914) and from the Minnesota Rate Cases, 230 U.S. 352 (1913), it is clear that the Commission is limited in its power over intrastate commerce to the protection of interstate commerce. See also North Carolina v. United States, 325 U.S. 507, 511 (1945); American Express Co. v. Caldwell, 244 U.S. 617, 
cause "undue prejudice" to "persons and localities in interstate commerce" or "unjust discrimination" to it. ${ }^{19}$ Undue prejudice exists when an intrastate rate for a specific commodity, or to and from a specific locality, is so far below the interstate level that shipments from outside the state are economically impossible. Unjust discrimination exists when the general level of all rates within a state is so low that intrastate revenues are insufficient to cover the allocable costs and charges. ${ }^{20}$ Consideration of the economic effects within the state of the proposed rate changes, which is beyond the scope of the ICC's inquiry, is the prerogative of the state commission. ${ }^{21}$ But the procedure followed in the Alabama case precludes the possibility of any such consideration.

The creation of this jurisdictional no-man's land will damage the state and its citizens in several ways. The absence of a state hearing may make impossible both a reasoned decision by the state commission as to what rates are desirable, and an effective argument in support of those rates before the ICC. Only through a hearing can the state commission obtain necessary information concerning (1) intrastate railroad costs and revenues, and (2) the effect on the state's economy which a rate change will produce. ${ }^{22}$ Furthermore, the extensive and specialized knowledge required to argue Section 13 cases means that a state commission is often the only body capable of presenting adequately the case for the interests within the state. ${ }^{23}$

625-26 (1917). The ICC itself has recognized this limitation: "[I]n every case which puts in question intrastate rates, the decisive factor is whether or not they affect interstate commerce injuriously to a considerable extent." Rates, Fares, and Charges of N.Y.C. R.R. Co., 59 I.C.C. $290,292(1920)$.

19. Interstate Commerce Act $\S 13(4)$, see note 3 supra.

20. For discussions indicating the distinction between prejudice and discrimination, see North Carolina v. United States, 325 U.S. 507, 512 et seq. (1945); Wis. R.R. Comm. v. Chicago, B. \& Q. RR Co., 257 U.S. 563 (1922); Rates, Fares, and Charges of N.Y.C. R.R. Co., 59 I.C.C. 290 (1920).

As these cases indicate, to prove prejudice it is necessary to show that the differential between specific rates is such that interstate shippers are impeded economically because of the unfair competition. To prove discrimination, which involves the general rate structure, it is necessary to show that the railsoad is incapable of making a fair return on its intrastate traffic, and that the intrastate traffic is not contributing its fair share of the earnings required to meet maintenance and operating costs. See North Carolina v. United States, 325 U.S. 507, 520 (1945).

21. See, e.g., Anchor Storage Co. v. Alton R. Co., 211 I.C.C. 307, 309 (1935) (ICC has no authority to prevent discrimination to intrastate commerce).

See also, e.g., ALA. CODE, tit. $48, \S 117$, (1940) which provides that special rates may be set for the transportation of specific commodities in order to aid in the development or continuation of industrial and agricultural enterprises.

22. See note 13 supra.

23. The determination as to whether intrastate revenues are sufficient to support allocable costs and charges is so complex as to lead to a reorganization-like wonderiand of more or less educated guesswork and statistical manipulation. It involves intricate accounting analysis to attempt to segregate intra-from interstate revenues and costs, and considerable experience to determine, for example, whether higher rates will aid the railroads by increasing their revenues, or whether lower rates, by increasing the volume of business, 
Adherence to the procedure followed in the Alabama case would substantially impede the setting of rates which are neither unduly harmful to interstate commerce nor as high as interstate rates. Both the Court and the ICC. have said that such intrastate rates may exist. ${ }^{24}$ But the ICC may consider only the interests of interstate commerce. ${ }^{25}$ For a fair solution to any rate differential problem, two questions must be answered: (1) whether interstate commerce is in fact being injured, and (2) to what extent rates must be changed to remove the injury. So far, if injury is found, the response of the ICC. has always been to equalize the rates. ${ }^{26} \mathrm{But}$ even if it discontinued this practice, the state commission, which has been prevented from making a prior attempt to mediate between inter- and intrastate interests, would be hampered by lack of facts from arguing for the most desirable possible adjudication.

When rates on commodities which move in intra- but not in interstate commerce within the state are regulated, the same considerations apply. Here there is no question of undue prejudice since there are no shipments from without the state in any case. ${ }^{27}$ But allegations of unjust discrimina-

will actually produce a greater margin between revenues and costs. Similarly, considerable knowledge and experience is required to determine if rate differentials are in fact the cause of reduced interstate shipments, or whether other factors would in any event prevent competition. This whole range of arguments has always been a legal necessity under the Section 13 standards, recently reaffirmed by the Supreme Court in the North Carolina case. See North Carolina v. United States, 325 U.S. 507, 520 (1945). The state commission has the facilities for obtaining needed data from the railroads, and the experience and expert knowledge required to interpret this data. Intrastate shippers may find it economically or actually impossible to prepare arguments strong enough to match those of the railroads.

The volume of intrastate movement may be large. In 1944, for example, intrastate freight revenues within Texas amounted to $\$ 87,798,436$, as compared with interstate revenues of $\$ 214,392,780$. Total intrastate revenues in that year were $\$ 118,213,008$, and total interstate revenues were $\$ 294,618,085$. RaIlROAd Statistical Sectron of tHe FiftYThird AnNual Report of the RaIl road Commission of Texas, for the year 1944. For statistics on the Alabama intrastate shipping affected by the instant case, see note 9 supra.

24. North Carolina v. United States, 325 U.S. 507, 512-514 (1945) (low intrastate passenger fare not prejudicial; no showing of discrimination; ICC reversed); Emergency Freight Charges Within Idaho, 213 I.C.C. 130, 131-32 (1935) (mere disparity between intraand interstate freight rates not sufficient to show Section 13 violation; state rates upheld).

25. See note 18 supra.

26. A possible reason for this policy is that equalizing the rates is certain to protect interstate commerce, and until the Alabama decision the state always had an opportunity to attempt a compromise solution. There is little doubt that the Commission would have the power to set rates so as to achieve a compromise solution itself. In fact, $\S 13(4)$ authorizes it to set maximum and minimum rates, so that it might define the area of non-discrimination and permit the states to set rates within those limits. However, the Commission is not primarily concerned with the interests of intrastate commerce or of the states; it is not the agency best equipped to decide what those interests are. Furthermore, because only effects upon interstate commerce are within its jurisdiction, there might be considerable difficulty obtaining the information required to achieve a compromise solution if the state were precluded from obtaining it at a prior hearing.

27. See text at note 20 supra. 
tion may arise. Absent a chance to hold a hearing, the state would have no opportunity to set the general level of intrastate rates high enough to overcome such allegations and at the same time to keep these selected rates as low as possible.

The damage to the state from the ICC's decision in this case far outweighs the advantage to interstate commerce, which consists entirely of the monetary gain to the railroads resulting from the time saved in by-passing the state commissions. Putting the new rates into effect several months earlier might result in a saving to the railroads of several million dollars. Because the increase in revenue during these months comes largely from within the state, however, the gain to the railroads is at the expense of intrastate shippers. ${ }^{28}$ Shifting the burden of this expense from the railroads to the intrastate shippers could be justified only on the assumption that the by-passing of the state commission would make no difference in the final determination of rates. As pointed out above, this assumption seems invalid.

On the other hand, the delay of which the railroads complain can largely be removed without any impairment of state powers. From the point of view of railroad revenues, the important Section 13 cases result from prior general interstate increases. If, at the same time they applied for interstate increases, the railroads filed intrastate increase applications with the appropriate states, the states should be able to complete their investigations by the time the ICC handed down its decision. They would then have only to relate their decision to that of the Commission. Since representatives from the commissions of all states involved are invited to attend the ICC's general increase hearings in an advisory capacity, ${ }^{29}$ state officials will be already familiar with both the federal and the state situations. Therefore, the step of relating their decision to that of the ICC should take little time. The delay between the ICC's decision on interstate rates and its reception of Section 13 complaints would therefore be short, and the loss to the railroads correspondingly small. The ICC could enforce this procedure by refusing to hear complaints until there has been a state hearing if a railroad has failed to make timely application to the state commission. On the other hand, if the railroad has filed such timely application, the ICC should act promptly regardless of whether the state commission has availed itself of the opportunity to hold an early hearing.

28. If the volume of inter-and intrastate traffic remains the same, intrastate shipments assume the total burden of the rate increases. If equalizing the rates results in an increase in interstate traffic at the expense of intrastate shipments, intrastate shippers lose as a result both of rate increases and of decline in business. If the increase in rates diverts traffic away from the railroads, the railroads may suffer such a diminution in total revenues as to be impelled to restore the prior low rates.

29. See Lindahl, Cooperation Between the Interstate Commerce Commission and the State Commissions in Railroad Regulation, 33 Mich. L. REv. 338, 368-69 (1935). See also Cooperative Agreement, Procedure Recommended, I.C.C. ANNuAL REPoRT 275 et seq. (1925). 